\title{
Board of Directors and CEO's Compensation: The Case of Listed European Firms
}

\author{
Hani El-Chaarani ${ }^{1} \&$ Zouhour El-Abiad ${ }^{2}$ \\ ${ }^{1}$ Faculty of Business Administration, Beirut Arab University, Lebanon \\ ${ }^{2}$ Faculty of Business Administration and Economic Sciences, Lebanese University, Lebanon \\ Correspondence: Hani El-Chaarani, Beirut Arab University, Lebanon. E-mail: h.shaarani@bau.edu.lb
}

Received: October 22, 2020

doi:10.5539/ass.v17n1p107
Accepted: November 18, 2020

Online Published: December 30, 2020

URL: https://doi.org/10.5539/ass.v17n1p107

\begin{abstract}
The aim of this research is to assess the role of the board of directors in determining CEO's compensation in the context of listed European companies for 3 fiscal years (2016-2017-2018). Based on a sample extracted from 11 European countries (France, Belgium, Germany, Italy, Spain, Ireland, Sweden, Denmark, Finland, United Kingdom and Netherlands), the results reveal the importance of board of directors characteristics in determining of CEO's compensation. The board size, CEO duality, the presence of independents directors and the existence of compensation committee have been shown as determinants of CEO's compensation.
\end{abstract}

Keywords: compensation, board of directors, board size, CEO duality, independents directors, compensation committee

\section{Introduction}

CEO compensation is a field of current affairs and ongoing development. It is considered as one of the topics with great interest to politicians, regulators, stockholders and other stakeholders. CEO's pay structure remains a topic of large debate, because of its impact on reducing agency costs and guarantying interest alignment between CEO and stockholders. Its privileged place in reflections and articles was mainly emphasized after the international economic crisis. In 2009, Towers Perrin (Note 1)'s study regarding compensations shows that the majority of large French companies have readjusted the compensation of their CEO's as a result of the economic crisis. Also, the international economic crisis has also directly influenced the CEO's compensation in the United States. For example, in the case of the US auto industry, which is going through an unprecedented liquidity and economic crisis, the executives of large corporates have agreed to reduce their salaries. Recently, the new report of Willis Towers Watson (2018) has declared that, on average, a CEO of the largest stock- listed companies in Western and Eastern Europe is paid $€ 5.8$ million in total as direct compensation (Note 2).

The aim of this research is to assess the role of the board of directors in determining CEO's compensation in the context of listed European companies. The question of the study is part of the overall governance framework and revolves around the identification of the internal determinants of the CEO's compensation, translated into the quality of the board of directors. Cross-country studies in the domain of CEO's compensation are difficult. This is partly due to methodological difficulties arising from cross-country differences in accounting and disclosure practices. The empirical study was based on the sample of publicly-traded companies listed in the S\&P Europe 350 Index from 11 EU countries: France, Belgium, Germany, Italy, Spain, Ireland, Sweden, Denmark, Finland, United Kingdom and Netherlands, for 3 fiscal years 2016, 2017 and 2018. The required information CEO's compensation, the structure and the composition of the board of directors were collected by mobilizing different databases. Annual reports have been also used to complete all missing data.

This article is organized into three sections. The first one presents the interaction between CEO's compensation and the characteristics of the board of directors. The second illustrates the research methodology. The third shows, explains and analyses the results of the empirical study.

\section{The Interaction Between CEO's Compensation and the Characteristics of the Board of Directors}

The board of directors is an internal governance body; it is the place of confrontation and resolution of conflicts of interest (Ben Ali, 2014; Broye \& Moulin, 2010; Charreaux \& Pitol-Belin, 1989) because it is the intermediary between shareholders and the management within the corporates. According to Charreaux and Pitol-Belin (1989), 
as well as Fama and Jensen (1983) and Ben Ali (2014), two main functions can be attributed to the board of directors: on the one hand, to evaluate and ratify long-term investment decisions, and on the other hand, monitor the performance of the main executives in order to align interests among different stakeholders (Note 3) to help establish new contacts outside the immediate environment. The analyses regarding the corporate board of directors were based primarily on agency theory (Corbetta \& Salvato, 2004). The board of directors aims to align the interests between the shareholders and the executives by limiting the opportunistic behavior of the latter, particularly with regard to their compensation. The literature suggests that the efficiency of board control depends primarily on its own characteristics designed by its size, composition, and structure. In order to empirically verify or invalidate the suggestions of the literature and the presuppositions of the agency theory, it seems appropriate to test the impact of the quality of the control exercised by the board of directors on the executive compensation within the listed European corporates by highlighting the influence of each of the characteristics (Note 4). Compensation depends on the quality of governance reflected in the efficiency of the board of directors. It is then possible to formulate the following hypothesis:

H1. The quality of CEO's compensation improves with the improvement of the quality of the board of directors.

The literature review indicates that the decision of board of directors, and especially the compensation policy depends on the following characteristics: size of the board (1.1), percentage of independents directors (1.2), presence of a compensation committee (1.3) and structure of the board (1.4).

\subsection{The Role of the Board Size}

Many researches have shown that the efficiency of the board of directors decreases with the increase of its size (Jensen \& Murphy, 2010; Fahlenbrach, 2009; Bhagat \& Black, 2002; Core et al., 1999; Yermack, 1996). When the board is oversized, it is considered less effective in coordinating and accomplishing its monitoring role.

When it comes to compensation, the efficiency of the control is reflected in the limit of excessive allocations, the increase in incentive shares and the pay-performance sensitivity. On the contrary, inefficiency is interpreted as the increase in compensation mainly from non-performance-related components and a decrease in the pay-performance sensitivity. Many researchers have revealed negative relationship between board size and executive compensation. Firth et al. (2007) show evidence of a negative relationship between board size and CEO's compensation on a sample of 549 listed Chinese companies. Feng et al. (2007) find that total director compensation is significantly negatively related to board size, by using a sample of 136 US Real Estate Investment Trusts. Ryan and and Wiggings (2004), show evidence of a negative relationship between board size and total director compensation, by using a sample of 1018 US firms.

From other point of view, large boards are considered to have a wider level of expertise. Thus, they are more effective in coordinating, controlling tasks and fixing executives compensations. Therefore, the link between the board size and the executive compensation remains uncertain and needs additional clarifications.

Hence, the following hypothesis is proposed:

H1.1 The quality of CEO's compensation improves when the size of the board of directors increases

Several sub - hypotheses related to the components of compensation are then considered below:

H1.1.-1 Total compensation decreases when the size of the board of directors increases

In addition to the total compensation, it was necessary to consider the composition of the total compensation (H1.1.-2, H1.1.-3, H1.1.-4, and H1.1.-5) and its sensitivity to performance (H1.1.-6). Hence, the following hypotheses are proposed:

H1.1.-2 The percentage of fixed compensation decreases when the size of the board of directors increases;

H1.1.-3 The percentage of variable compensation increases when the size of the board of directors increases;

H1.1.-4 The percentage of the CEO's attendance fees decreases when the size of the board of directors increases;

H1.1.-5 The percentage of non - financial benefits (Note 5) decreases when the size of the board of directors increases;

H1.1.-6 The pay-performance sensitivity increases when the size of the board of directors increases.

\subsection{The Role of Independent Directors}

According to the governance reports, the effective board of directors will have to give a prominent place to the independent and qualified external experts. Indeed, the presence of external personalities, the "outsiders", aims to provide the council with skills, an objective judgment and constituting a regulatory element, while bringing a 
new and original point of view.

This configuration of the board, favored by the existence of the independents, therefore plays an important role in ensuring respect for internal and external balances (Pichard-Stamford, 2002). Independent directors evaluate the performance of executives, determine their compensation, and even replace them if necessary (Core et al., 1995). In fact, independent directors are interested in reporting their managerial skills on the labor market (Fama \& Jensen, 1983; Weisbach, 1988). They most often have the control expertise of the management team and are experts in internal organizational control (Fama \& Jensen, 1983). Compared to internal directors, the literature suggests that independents are likely to dismiss low performance executives (Switzer \& Kelly, 2006). The percentage of independent directors then influences the efficiency of the control exercised by the board of directors, particularly as regards executive compensation control (Victor et al., 2013; Chau \& Gray, 2010; Westphal \& Zajac, 1994).

However, empirical findings are still conflicting. Several results were not consistent with the expectations of the agency theory, according to which the pay of executive board members should be negatively related to the number of non - executives. Canzavan-Jenya et al. (2008) found that the percentage of independent directors is positively related to the fixed and total compensation of the executives within listed French corporates. Feng et al. (2007) find that when the board includes more non- executive members, the total pay to executive board members increases. This result is in line with the findings of Fernandes (2008) and Brick et al. (2006).

Therefore, the real role of outsiders and independent directors presents serious doubts and needs to be justified by new empirical evidences. For this reason, the following hypothesis is proposed:

H1.2 The quality of CEO's compensation improves when the percentage of independents directors increases.

The distinction between the different components of compensation allows the formulation of the following hypotheses:

H1.2.-1 Total compensation decreases with the increasing of the percentage of independent directors;

H1.2.-2 The percentage of fixed compensation decreases with the increasing of the percentage of independent directors;

H1.2.-3 The percentage of the variable compensation increases with the increasing of the percentage of independent directors;

H1.2.-4 The percentage of CEO's attendance fees decreases with the increasing of the percentage of independent directors;

H1.2.-5 The percentage of non-financial benefits decreases with the increasing of the percentage of independent directors;

H1.2.-6 The pay-performance sensitivity increases with the increasing of the percentage of independent directors.

\subsection{The Role of the Compensation Committee}

The determination of executive compensation is often assigned to the compensation committee, which is often referred to as the "Compensation and Nomination Committee". This committee, which corresponds to a governance structure, plays a central role in setting the variable portion of executive compensation. It also defines the setting of the variable portion so that it is both consistent with the assessment of executive performance and the medium-term strategy of the corporate. The committee also controls the annual application of the defined rules and should also assess all the compensations and benefits received by the executives (Bebchuck \& Fried, 2004).

Corporates that have not adopted a compensation committee on their board, theoretically offer more opportunities for their executives to benefit from higher non-performance related compensation. However, the objectivity of the compensation is not only associated with the presence of the compensation committee. It is rather the independence of its members that guarantees its efficiency (Conyon and Peck, 1998). Good governance practices emphasize the presence of a compensation committee that can provide technical assistance to the board of directors in determining executive compensation. This committee thus determines the performance indicators on which the executive compensation must be fixed and formats the proposals to be submitted to the board. It then controls the achievement of pre-established performance targets. The presence of this committee in European corporates is useful for the evaluation of compensation and the respect of good practices. However, the efficiency of this committee depends on its composition. Canzavan-Jenya et al. (2008) have observed that the compensation committee has a negative influence on the fixed and total compensation of 
the executives within the French corporates, without being in relation with the amounts awarded in the form of bonuses. Conyon and Peck (1998) have already found that the proportion of independent executives on the Compensation Committee is positively related to senior executive compensation and the pay performance sensitivity. It is then possible to postulate that:

H1.3 The quality of CEO's compensation improves with the existence of compensation committee

Similarly, the following sub-hypotheses are thus proposed:

H1.3.-1 Total compensation decreases with the existence of compensation committee;

H1.3.-2 The percentage of fixed compensation decreases with the existence of compensation committee;

H1.3.-3 The percentage of variable compensation increases with the existence of compensation committee;

H1.3.-4 The percentage of CEO's attendance fees decreases with the existence of compensation committee;

H1.3.-5 The percentage of non- financial benefits decreases with the existence of compensation committee;

H1.3.-6 The pay-performance sensitivity increases with the existence of compensation committee.

\subsection{The Separation Between the Role of CEO and the Chairman of the Board of Directors}

When companies are subject to agency costs, the role of the board of directors is strengthened because it is the guarantor of the respect of shareholders' interests. If the CEO also chairs the board of directors, the power of his control increases by accumulating the two positions. This double position, known as CEO duality, reduces the control over compensation decisions. CEO attempts to reduce its risk and compensation policy loses from its efficiency (Krause et al., 2014). So, duality acts negatively on the efficiency of the control of the council within companies. The executive then has a margin of discretion in determining his compensation.

On the contrary, the separation between the control and decision-making functions contributes to the improvement of the efficiency of the control applied by the board. The chairman of the board is supposed then to control objectively the fixing of the executives compensations. Bruce and Skovoroda (2015) found that the executive's ability to influence their compensation is greater when the board of directors is weak and executives are strong. So, the separation between the role of CEO and the chairman of the board of directors is associated with a better quality for executive compensation.

Hence, the following hypothesis is proposed:

H1.4 The quality of CEO's compensation improves with the separation between CEO and chairman of the board of directors.

The hypotheses relating to H1.4 are then as follows:

H1.4.-1 Total compensation decreases with the separation of functions;

H1.4.-2 The percentage of fixed compensation decreases with the separation of functions;

H1.4.-3 The percentage of variable compensation increases with the separation of functions;

H1.4.-4 The percentage of CEO's attendance fees decreases with the separation of functions;

H1.4.-5 The percentage of non-financial benefits decreases with the separation of functions;

H1.4.-6 The pay-performance sensitivity increases with the separation of functions.

\section{Methodology}

The methodology consists in identifying the sample of the study (2.1), operationalizing the variables (2.2), data collection (2.3) and determining the statistical tests (2.4).

\subsection{Sample of the Study}

By considering past academic researches, several studies had focused on exploring the efficiency of the board of directors, by examining its effect on the executive compensation, in one single country. For this reason, the main aim of this study is to provide additional scientific information on the role of characteristics of the board of directors in determining the executive compensation in a cross-country sample. The empirical study is based on the sample of publicly-traded companies listed in the S\&P Europe 350 Index from 11 EU countries: France, Belgium, Germany, Italy, Spain, Ireland, Sweden, Denmark, Finland, United Kingdom and Netherlands, for 3 fiscal years 2016, 2017 and 2018.

\subsection{Definition of Variables}

The following table presents the definition of the different variables (CEO compensation and quality of board of 
directors) used in this study.

Table 1. Variables on CEO compensation and characteristics of the board of directors

\begin{tabular}{|c|c|c|}
\hline & & Variables descriptions \\
\hline \multirow{12}{*}{$\begin{array}{l}\text { CEO's } \\
\text { compensa- } \\
\text { tion }\end{array}$} & $\begin{array}{c}\text { Total } \\
\text { Compensation }\end{array}$ & $\begin{array}{l}\text {-Average amount of total compensation }{ }_{(t)}=\text { average of total CEO's compensation for three } \\
\text { years }(2016,2017 \text { and 2018) }\end{array}$ \\
\hline & & -Average of the percentage of fixed compensation for 2016, 2017 and 2018. \\
\hline & & $-\%$ fixed compensation $_{(\mathrm{t})}=$ fixed compensation $_{(\mathrm{t})} /$ total compensation $_{(\mathrm{t})}$ \\
\hline & & -Average of the percentage of variable compensation for 2016, 2017 and 2018. \\
\hline & Composition of & $-\%$ variable compensation $_{(\mathrm{t})}=$ variable compensation $(\mathrm{t}) /$ total compensation $_{(\mathrm{t})}$ \\
\hline & $\begin{array}{c}\text { total } \\
\text { compensation }\end{array}$ & -Average of the percentage of directors' attendance fees for 2016, 2017 and 2018. \\
\hline & & $-\%$ CEO's attendance fees $(\mathrm{t})=$ CEO's attendance fees $(\mathrm{t}) /$ total compensation $_{(\mathrm{t})}$ \\
\hline & & -Average of the percentage of non-financial benefits for 2016, 2017 and 2018. \\
\hline & & $-\%$ of non- financial benefits ${ }_{(\mathrm{t})}=$ non-financial benefits ${ }_{(\mathrm{t})} /$ total compensation ${ }_{(\mathrm{t})}$ \\
\hline & Pay-performance & $\begin{array}{l}\text {-Average of the sensitivity of total compensation to the selected performance indicators } \\
\text { (ROE, ROA and ratio of Marris) }\end{array}$ \\
\hline & sensitivity $(\mathrm{t})$ & 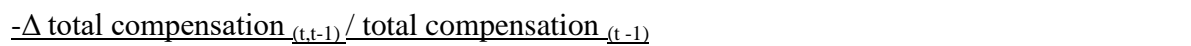 \\
\hline & & $\Delta$ performance $_{(\mathrm{t}, \mathrm{t}-1)} /$ performance $_{(\mathrm{t}-1)}$ \\
\hline \multirow{5}{*}{$\begin{array}{l}\text { Quality of } \\
\text { the board } \\
\text { of the } \\
\text { directors }\end{array}$} & $\begin{array}{l}\text { Size of the } \\
\text { board }_{(\mathrm{t}-1)}\end{array}$ & $\begin{array}{l}\text {-Binary variable: if the size of the board }{ }_{(\mathrm{t}-1)} \text { is greater than the average of the size of the } \\
\text { boards }=1 \text {, if the size of the board }{ }_{(\mathrm{t}-1)} \text { is less than the average of the size of the boards }=0\end{array}$ \\
\hline & $\begin{array}{l}\text { Independent } \\
\text { directors }_{(\mathrm{t}-1)}\end{array}$ & $\begin{array}{l}\text {-Binary variable: if the percentage of independent directors }(t-1) \text { is above the average of } \\
\text { percentage of independent directors of all companies }=1 \text {, if the percentage of independent } \\
\text { directors }_{(t-1)} \text { is below the average of percentage of independent directors of all companies }=0\end{array}$ \\
\hline & & $-\%$ of independent directors ${ }_{(\mathrm{t}-1)}=$ number of independent directors $_{(\mathrm{t}-1)} /$ size of board $(\mathrm{t}-1)$ \\
\hline & $\begin{array}{l}\text { Compensation } \\
\text { committee }_{(\mathrm{t}-1)}\end{array}$ & $\begin{array}{l}\text {-Binary variable: presence of the committee } \mathrm{t}_{(-1)}=1 \\
\text { absence of the committee }_{(\mathrm{t}-1)}=0\end{array}$ \\
\hline & $\begin{array}{l}\text { Structure of the } \\
\text { board of } \\
\text { directors }_{(\mathrm{t}-1)}\end{array}$ & -Binary variable: separation of functions ${ }_{(\mathrm{t}-1)}=1$, Duality of functions ${ }_{(\mathrm{t}-1)}=0$ \\
\hline
\end{tabular}

\subsection{Data Collection}

Data related to the composition of the board of directors was collected through two databases, "AMADEUS" and "DAFSALIENS". Other databases and sources were also mobilized to complete missing data, such as "FACTIVA" and "PROXINVEST". Elements on compensation of the company's CEO were hand-collected through analyzing companies' annual reports for 2016, 2017 and 2018, downloaded through “INFINANCIALS” database.

\subsection{Statistical Tests}

The Mann-Whitney test corresponds to a nonparametric identity test performed on two independent samples from numerical or ordinal variables. It deals with the fact that two series of numerical or ordinal values come from the same distribution. It is nonparametric because it does not make any hypothesis about the shape of population distributions. Its rule of interpretation is simple: it is sufficient that the P-value is less than 0.05 to conclude that the difference between the two samples is significant.

\section{The Empirical Results}

The univariate analysis focuses on analyzing the role of the board of directors in determining the CEO's compensation.

\subsection{The Size of the Board and CEO's Compensation}

In order to test the impact of the size of the board on the efficiency of the control translated in terms of differences in the averages of the components of CEO's compensation, it was necessary to distinguish companies with a large board from those with a small board.

The table bellow shows the existence of a statistically significant difference between Europeans listed companies with above-average board size and those with below-average board size. The statistical significance corresponds respectively to the thresholds of $1 \%, 5 \%$ and $10 \%$. A lower probability than the threshold values shows the rejection of the null hypothesis ("no difference between the averages of the two groups"). These results illustrate that companies with below-average board size assign higher total compensation to their CEO. They also grant a 
higher percentage of fixed compensation, CEO's attendance fees and non-financial benefits. However, they attribute a lower percentage for variable compensation and pay- performance sensitivity. The statistical significance of all these differences shows that the size of the board of directors influences CEO's compensation. Consequently, hypotheses H1.1.-1; H1.1.-2; H1.1.-3; H1.1.-4; H1.1.-5; H1.1.-6 are confirmed.

Table 2. Comparison of the averages of CEO's compensation as a function of the board size (Mann-Whitney test)

\begin{tabular}{|c|c|c|c|c|c|c|c|}
\hline & & \multicolumn{4}{|c|}{ Listed European companies } & \multirow{3}{*}{$\mathrm{Z}$} & \multirow{3}{*}{$\begin{array}{c}\text { Asymptotic } \\
\text { Meaning }\end{array}$} \\
\hline & & \multicolumn{2}{|c|}{$\begin{array}{c}\text { Board Size below } \\
\text { average }\end{array}$} & \multicolumn{2}{|c|}{$\begin{array}{c}\text { Board Size above } \\
\text { average }\end{array}$} & & \\
\hline & & Average & $\mathrm{N}$ & Average & $\mathrm{N}$ & & \\
\hline \multicolumn{2}{|c|}{ Total Compensation } & 861427.04 & 218 & 460515.69 & 120 & -7.116 & $0.000^{(* * *)}$ \\
\hline \multicolumn{2}{|c|}{ Percentage of fixed compensation } & $78.35 \%$ & 218 & $59.64 \%$ & 120 & -3.721 & $0.000^{(* * *)}$ \\
\hline \multicolumn{2}{|c|}{ Percentage of variable compensation } & $17.28 \%$ & 218 & $34.35 \%$ & 120 & -3.312 & $0.001^{(* * *)}$ \\
\hline \multirow{2}{*}{\multicolumn{2}{|c|}{$\begin{array}{l}\text { Percentage of CEO's attendance fees } \\
\text { Percentage of non-financial benefits }\end{array}$}} & $4.38 \%$ & 218 & $2.16 \%$ & 120 & -3.430 & $0.001^{(* * *)}$ \\
\hline & & $2.09 \%$ & 218 & $1.49 \%$ & 120 & -2.336 & $0.020^{(* *)}$ \\
\hline \multirow{3}{*}{$\begin{array}{l}\text { Pay-performance } \\
\text { sensitivity }\end{array}$} & ROE & -0.408 & 147 & 1.617 & 76 & -3.124 & $0.002^{(* * *)}$ \\
\hline & ROA & 0.162 & 147 & 0.381 & 76 & -2.412 & $0.048^{(* *)}$ \\
\hline & Ratio of Marris & 0.012 & 147 & 0.745 & 76 & -2.425 & $0.024^{(* *)}$ \\
\hline
\end{tabular}

$(* * *)$ statistical significance at the $1 \%$ threshold, $(* *)$ statistical significance at the $5 \%$ threshold, $(*)$ statistical significance at the $10 \%$ threshold, $\left({ }^{\text {n.s }}\right)$ not significant

Due to the increase in the part of the variable compensation and the pay-performance sensitivity against the decrease in the part of fixed compensation and non- financial benefits, the hypothesis H1.1 stating that "the quality of CEO's compensation improves when the size of the board of directors increases", is confirmed.

\subsection{Independent Directors and CEO's Compensation}

Admitting that the control exercised by the independent directors is not limited to the level of total compensation, it's important to test the impact of the percentage of independent directors on the determination of the CEO's compensation within the listed European corporates (Table 3).

According to Table 3, when the percentage of independent directors is higher than the average, the total compensation and the percentage of variable compensation increase. However, the percentage of fixed compensation of CEO in listed European companies' decreases in a significant way. Thus, independent directors try to align CEO's total compensation and its composition (percentages of fixed and variable shares) with market standards. Despite the statistical significance of the differences at the $1 \%$ and $5 \%$ thresholds, it is necessary to emphasize the importance of fixed shares $(72.14 \%)$ versus variable shares $(24.05 \%)$ that reflect the challenges of independent directors.

Table 3. Comparison of the averages of CEO's compensation as a function of the percentage of independent directors (Mann - Whitney test)

\begin{tabular}{|c|c|c|c|c|c|c|c|}
\hline & & \multicolumn{4}{|c|}{ Listed European companies } & \multirow{3}{*}{$\mathbf{Z}$} & \multirow{3}{*}{$\begin{array}{l}\text { Asymptotic } \\
\text { Meaning }\end{array}$} \\
\hline & & \multicolumn{2}{|c|}{$\begin{array}{l}\text { Percentage of independents } \\
\text { directors below average }\end{array}$} & \multicolumn{2}{|c|}{$\begin{array}{l}\text { Percentage of independents } \\
\text { directors above average }\end{array}$} & & \\
\hline & & Average & $\mathrm{N}$ & Average & $\mathrm{N}$ & & \\
\hline \multicolumn{2}{|c|}{ Total Compensation } & 392423.88 & 177 & 775047.59 & 161 & -6.338 & $0.000^{(* * *)}$ \\
\hline \multicolumn{2}{|c|}{ Percentage of fixed compensation } & $77.42 \%$ & 177 & $52.14 \%$ & 161 & -2.247 & $0.025^{(* *)}$ \\
\hline \multicolumn{2}{|c|}{ Percentage of variable compensation } & $15.91 \%$ & 177 & $45.08 \%$ & 161 & -3.405 & $0.001^{(* * *)}$ \\
\hline \multicolumn{2}{|c|}{ Percentage of CEO's attendance fees } & $4.51 \%$ & 177 & $1.25 \%$ & 161 & -0.693 & $0.488^{(\mathrm{n} . \mathrm{s})}$ \\
\hline \multicolumn{2}{|c|}{ Percentage of non- financial benefits } & $2.16 \%$ & 177 & $1.53 \%$ & 161 & -0.829 & $0.407^{\text {(n.s) }}$ \\
\hline \multirow{3}{*}{$\begin{array}{l}\text { Pay-perform } \\
\text { ance } \\
\text { sensitivity }\end{array}$} & ROE & 0.497 & 124 & 0.013 & 99 & -0.435 & $0.664^{(\mathrm{n} . \mathrm{s})}$ \\
\hline & ROA & -0.043 & 124 & 0.587 & 99 & -1.319 & $0.187^{\text {(n.s) }}$ \\
\hline & Ratio of Marris & 0.819 & 124 & 0.214 & 99 & -0.210 & $0.834^{(\mathrm{n} . \mathrm{s})}$ \\
\hline
\end{tabular}

$(* * *)$ statistical significance at the $1 \%$ threshold, $(* *)$ statistical significance at the $5 \%$ threshold, $(*)$ statistical significance at the $10 \%$ threshold, $\left({ }^{\text {n.s }}\right)$ not significant

However, due to the lack of any statistical significance regarding differences in pay- performance sensitivity, the 
efficiency of the control exercised by independent directors over the sensitivity of CEO's compensation to accounting and / or stock market performance remains unclear.

Thus, the hypotheses, H1.2.-2 and H1.2.-3 are confirmed. On the other hand, the hypotheses; H1.2.-1; H1.2.-4; H1.2.-5 and H1.2.-6 are not confirmed. Consequently, the hypothesis H1.2 stating that "The quality of CEO's compensation improves when the percentage of independent directors increases", is partially confirmed.

\subsection{The Presence of a Compensation Committee}

Table 4, presented below, illustrates the differences in CEO's compensation for listed European companies as a function of the existence or the absence of the compensation committee.

Table 4. Comparison of CEO's compensation averages as a function of the presence of a compensation committee (Mann - Whitney test)

\begin{tabular}{|c|c|c|c|c|c|c|c|}
\hline & & \multicolumn{4}{|c|}{ Listed European companies } & \multirow{3}{*}{$\mathbf{Z}$} & \multirow{3}{*}{$\begin{array}{c}\text { Asymptotic } \\
\text { Meaning }\end{array}$} \\
\hline & & \multicolumn{2}{|c|}{$\begin{array}{c}\text { Absence of } \\
\text { compensation committee }\end{array}$} & \multicolumn{2}{|c|}{$\begin{array}{c}\text { Presence of } \\
\text { compensation committee }\end{array}$} & & \\
\hline & & Average & $\mathrm{N}$ & Average & $\mathrm{N}$ & & \\
\hline Total Cor & nsation & 466167.03 & 219 & 860683.97 & 119 & -7.903 & $0.000^{(* * *)}$ \\
\hline Percentage of fi & compensation & $79.41 \%$ & 219 & $66.61 \%$ & 119 & -5.219 & $0.000^{(* * *)}$ \\
\hline Percentage of var & compensation & $16.10 \%$ & 219 & $26.57 \%$ & 119 & -5.252 & $0.000^{(* * *)}$ \\
\hline Percentage of CE & attendance fees & $2.29 \%$ & 219 & $4.15 \%$ & 119 & -0.795 & $0.426^{(n . s)}$ \\
\hline Percentage of nor & Iancial benefits & $1.93 \%$ & 219 & $1.77 \%$ & 119 & -0.516 & $0.606^{(\mathrm{n} . \mathrm{s})}$ \\
\hline \multirow{3}{*}{$\begin{array}{l}\text { Pay-performance } \\
\text { sensitivity }\end{array}$} & ROE & -0.092 & 151 & 1.067 & 72 & -0.095 & $0.924^{(\mathrm{n} . \mathrm{s})}$ \\
\hline & ROA & 0.224 & 151 & 0.263 & 72 & -0.049 & $0.961^{(\mathrm{n} . \mathrm{s})}$ \\
\hline & Ratio of Marris & 1.242 & 151 & -0.898 & 72 & -1.154 & $0.248^{(\mathrm{n} . \mathrm{s})}$ \\
\hline
\end{tabular}

$(* * *)$ statistical significance at the $1 \%$ threshold, $(* *)$ statistical significance at the $5 \%$ threshold, $(*)$ statistical significance at the $10 \%$ threshold, $\left({ }^{\mathrm{n} . \mathrm{s}}\right)$ not significant

Listed European companies with a compensation committee offer for their CEO a higher total compensation and a higher percentage of variable compensation. On the other hand, those without a committee offer less total compensation and more percentage of fixed compensation. These differences are statistically significant at the $1 \%$ threshold. The control exercised by the compensation committee is then interpreted as the alignment of total compensation with market standards and the moderation of the fixed compensation compared to the variable compensation. CEO's compensation is found to be significantly higher for companies that have adopted a compensation committee that is consistent with the results of Main and Johnston (1993), Conyon and Peck (1998) and Anderson and Bizjak (2003). Given the absence of the statistical significance between the differences in averages, the interpretation of the increase in CEO's attendance fees and the decrease in non-financial benefits with the presence of compensation committee remains nuanced. However, the role of the compensation committee is not limited to the change in the level of total compensation or its composition. It must indeed ensure the alignment of the CEO's compensation with the performance of the European listed companies. This role is not assumed because of the absence of the statistical significance between the differences in averages of the pay-performance sensitivity ( $p>0.1$ ).

Thus, the hypotheses H1.3.-2 and H1.3.-3 are confirmed. However, the hypotheses H1.3.-1; H1.3.-4; H1.3.-5 and H1.3.-6 are not confirmed

This contributes to a partial confirmation of hypothesis H1.3, which states that "The quality of CEO's compensation improves with the existence of compensation committee"

\subsection{The Impact of the Board Structure}

With the aim of testing the impact of the structure of the board of directors on CEO's compensation, it was necessary to distinguish listed European companies with duality structure from those who have a combined structure (Table 5).

Results show that the average of total CEO's compensation is lower with the separation of functions at $1 \%$ threshold. This result is different from the findings of Conyon and Peck (1998) and Ramaswamy et al. (2000) who found that duality of functions does not influence CEO's compensation in a meaningful way.

However, the separation of functions is associated with a decrease in the percentage of fixed compensation, that of CEO's attendance fees, and also that of non- financial benefits. However, the percentage of CEO's variable 
compensation increases with a significant difference with the separation of the functions. The absence of the statistical significance for the differences in pay-performance sensitivity ( $p>0.1$ ) limits the explanatory contribution of the separation of functions on CEO's compensation in listed European companies. Thus, the hypotheses H1.4.-1; H1.4.-2; H1.4.-3; H1.4.-4 and H1.4.-5 are confirmed. On the other hand, the hypotheses and H1.4.-6 are not confirmed. Consequently, the hypothesis H1.4, stating that "The quality of CEO's compensation improves with the separation between CEO and chairman of board of directors functions", is partially confirmed.

Table 5. Comparison of CEO's compensation averages as a function of the board structure (Mann - Whitney test)

\begin{tabular}{|c|c|c|c|c|c|c|c|}
\hline & & \multicolumn{4}{|c|}{ Listed European corporates } & \multirow{3}{*}{$\mathbf{Z}$} & \multirow{3}{*}{$\begin{array}{c}\text { Asymptotic } \\
\text { Meaning }\end{array}$} \\
\hline & & \multicolumn{2}{|c|}{ Duality of functions } & \multicolumn{2}{|c|}{ Seperation of functions } & & \\
\hline & & Average & $\mathrm{N}$ & Average & $\mathrm{N}$ & & \\
\hline Total Cc & ensation & 806756.83 & 139 & 513086.75 & 199 & -3.430 & $0.001^{(* * *)}$ \\
\hline Percentage of $\mathrm{f}$ & d compensation & $76.14 \%$ & 139 & $63.14 \%$ & 199 & -2.566 & $0.017^{(* *)}$ \\
\hline Percentage of va & le compensation & $17.96 \%$ & 139 & $32.42 \%$ & 199 & -2.770 & $0.006^{(* * *)}$ \\
\hline Percentage of $\mathrm{Cl}$ & s attendance fees & $3.46 \%$ & 139 & $2.23 \%$ & 199 & -3.145 & $0.002^{(* * *)}$ \\
\hline Percentage of $n$ & inancial benefits & $2.19 \%$ & 139 & $1.42 \%$ & 199 & -3.085 & $0.002^{(* * *)}$ \\
\hline \multirow{3}{*}{$\begin{array}{l}\text { Pay-performance } \\
\text { sensitivity }\end{array}$} & ROE & -0.503 & 91 & 0.823 & 132 & -1.358 & $0.174^{(\mathrm{n} . \mathrm{s})}$ \\
\hline & ROA & 0.355 & 91 & 0.475 & 132 & -0.260 & $0.795^{(\mathrm{n} . \mathrm{s})}$ \\
\hline & Ratio of Marris & 0.379 & 91 & 0.669 & 132 & -0.465 & $0.642^{(\mathrm{n} . \mathrm{s})}$ \\
\hline
\end{tabular}

$(* * *)$ statistical significance at the $1 \%$ threshold, $(* *)$ statistical significance at the $5 \%$ threshold, $(*)$ statistical significance at the $10 \%$ threshold, $\left({ }^{\text {n.s }}\right)$ not significant

In conclusion, hypothesis H1, stating that "The quality of CEO's compensation improves with the improvement of the quality of the board of directors", is also partially confirmed.

\section{Discussion}

The objective of this study is to assess the role of the board of directors in determining CEO's compensation in listed European companies. The results of this study reveal the importance of board size and independent directors on the compensation of CEO. The results show that listed European companies with small board size (below-average) allocate higher level of total compensation to their CEO. They also pay a higher percentage of fixed compensation, CEO's attendance fees and non-financial benefits. The existence of independent directors (higher than the average) was associated with high level of total compensation and variable compensation. However, it leads to a decrease in the percentages of fixed compensation.

The presence of a compensation committee has a positive impact on total and variable compensation of CEO in European listed companies. So, European listed companies without a compensation committee offer less total CEO's compensation and more percentage of fixed shares. However, the compensation committee should ensure that CEO's compensation is aligned with the companies' performance. This role has not been noticed because the pay-performance sensitivity does not differ between companies that have adopted a compensation committee and those that do not have such a structure.

Results also illustrate a lower average of CEO's compensation and a decrease in the percentage of fixed compensation, that of CEO's attendance fees, and also that of non-financial benefits with the separation of functions. These findings are affected by the ownership structure in listed European companies, which are characterized by high ownership concentration. Therefore, the legal system and the governance structure of European firms should be improved to constrain the expropriation of shareholders (El-Chaarani, 2014; El-Chaarani, 2015; El-Chaarani 2017).

However, this study has some limitations. Indeed, the agency theory presents only one point of view. So, the use of other theories can enrich the vision of the researcher. The choice of the CEO's compensation variables has a number of difficulties, mainly related to the empirical limits due to insufficient information on the CEO's compensation within European listed companies (Balsmeier \& Czarnitzki, 2015).

This research, and the results it produces, identifies a number of issues that require further research. First, some issues related to our model deserve further investigation. It may therefore be interesting to integrate other paradigms, such as social networks, into the agency theory, or to adopt a broader vision by focusing on "stakeholders". It will also be interesting to take the compensation of the entire executive team. 


\section{References}

Anderson, R. C., \& Bizjak, J. M. (2003). An Empirical Examination of the Role of the CEO and the Compensation Committee in Structuring Executive Pay. Journal of Banking \& Finance, 27(7), 1323-1348. https://doi.org/10.1016/S0378-4266(02)00259-5

Balsmeier, B., \& Czarnitzki, D. (2015). Ownership Concentration, Institutional Development and Firm Performance in Central and Eastern Europe. Managerial and Decision Economics, 38(2), 145-162. https://doi.org/10.1002/mde.2751

Bebchuck, L. A., \& Fried, J. M. (2004). Pay without performance: The Unfulfilled Promise of Executive Compensation. Harvard University Press.

Ben, A. C. (2014). L'impact des attributs du conseil d'administration sur la rémunération du dirigeant. Gestion, 31(4), 133-153. https://doi.org/10.3917/g2000.314.0133

Bhagat, S., \& Black, B. (2002). The Non-Correlation Between Board Independence and Long-Term Firm Performance. Journal of Corporation Law, 27, 231-273.

Brick, I. B., Palmon, O., \& Wald, J. K. (2006). CEO Compensation, Director Compensation and Firm Performance: Evidence of Cronyism. Journal of Corporate Finance, 12(3), 403-423. https://doi.org/10.1016/j.jcorpfin.2005.08.005

Broye, G., \& Moulin, Y. (2010). Rémunération des dirigeants et gouvernance des entreprises: le cas des entreprises françaises cotées. Revue Finance Contrôle Stratégie, 13(1), 67-98.

Bruce, A. C., \& Skovoroda, R. (2015). The Empirical Literature on Executive Pay: Context. The Pay-Performance Issue and Future Directions, High Pay Centre, London.

Canzavan-Jeny A., Margaine, J., \& Missonier-Piera, F. (2008). CEO Compensations in a Stakeholders' Regime: An empirical Investigation with French Listed Companies. Retrieved from https://halshs.archives-ouvertes.fr/halshs-00460167

Charreaux, G., \& Pitol-Belin, J. P. (1989). Image et réalités du conseil d'administration. Revue française de Gestion, Revue Française de Gestion, (74), 49-61.

Chau, G., \& Gray, S. J. (2010). Family Ownership, Board Independence and Voluntary Disclosure: Evidence from Hong Kong. Journal of International Accounting, Auditing and Taxation, 19, 93-109. https://doi.org/10.1016/j.intaccaudtax.2010.07.002

Conyon, M. G., \& Peck, S. (1998). Board Control, Remuneration Committees, and Top Management Compensation. Academy of Management Journal, 41, 146-157. https://doi.org/10.2307/257099

Corbetta, G., \& Salvato, C. A. (2004). The Board of Directors in Family Firms: One Size Fits All? Family Business Review, 17, 119-134. https://doi.org/10.1111/j.1741-6248.2004.00008.x

Core, J. E., Holthausen, R. W., \& Larcker, D. F. (1995). Corporate Governance, CEO compensation and firm performance. Journal of Financial and Quantitative Analysis, 32, 331-344.

Core, J. E., Holthausen, R. W., \& Larcker, D. F. (1999). Corporate Governance, Chief Executive Officer Compensation, and Firm Performance. Journal of Financial Economics, 51, 371-406. https://doi.org/10.1016/S0304-405X(98)00058-0

El-Chaarani, H. (2014). The impact of corporate governance on the performance of Lebanese banks. The International Journal of Business and Finance Research, 8(5), 35-46.

El-Chaarani, H. (2015). The impact of financial and legal structures on the performance of European listed firms. The International Journal of Business and Finance Research, 9(2), 39-52.

El-Chaarani, H. (2017). The mutual impacts of corporate governance dimensions and legal protection systems on the performance of European banks: A post-crisis study. University of Piraeus. International Strategic Management Association. https://doi.org/10.35808/ersj/658

Fahlenbrach, R. (2009). Shareholder Rights, Boards, and CEO Compensation. Review of Finance, 13(1), 81-113. https://doi.org/10.1093/rof/rfn011

Fama, E. F., \& Jensen, M. C. (1983). Separation of Ownership and Control. Journal of law and Economics, 26, 301-326. https://doi.org/10.1086/467037

Feng, Z., Ghosh, C., \& Sirmans, C. F. (2007). Director Compensation and CEO Bargaining Power in REITs. The 
Journal of Real Estate Finance and Economics, 35(3), 225-251. https://doi.org/10.1007/s11146-007-9043-9

Fernandes N. (2008). EC: Board Compensation and Firm Performance: The Role of "Independent" Board Members. Journal of Multinational Financial Management, 18(1), 30-44. https://doi.org/10.1016/j.mulfin.2007.02.003

Firth, M., Fung, P. M., \& Olivier, M. R. (2007). How Ownership and Corporate Governance Influence Chief Executive Pay in China's Listed Firms. Journal of Business Research, 60(7), 776-785. https://doi.org/10.1016/j.jbusres.2007.01.014

Jensen, M. C., \& Murphy, K. J. (2010). CEO Incentives: It's Not How Much You Pay, But How. Journal of Applied Corporate Finance, 22(1). https://doi.org/10.1111/j.1745-6622.2010.00262.x

Krause, R., Semadeni, M., \& Cannella, A. A. (2014). CEO Duality: A Review and Research Agenda. Journal of Management, 14(1), 252-282. https://doi.org/10.1177/0149206313503013

Main, B., \& Johnston, J. (1993). Remuneration committees and corporate governance. Accounting and Business Research, 23, 351-362. https://doi.org/10.1080/00014788.1993.9729903

Pichard-Stamford, J.-P. (2002). L'enracinement des dirigeants familiaux, in La gestion de l'entreprise familiale. ouvrage collectif sous la direction de Hirigoyen G. et Caby J., Paris, Economica (pp. 57-80).

Ramaswamy, K., Veliyath, R., \& Gomes, L. (2000). A study of the Determinants of CEO Compensation in India. Management International Review, 40, 167-191.

Ryan, H. E., \& Wiggings, R. A. (2004). Who is in Whose Pocket? Director Compensation, Board Independence, and Barriers to Effective Monitoring. Journal of Financial Economics, 73(3), 497-524. https://doi.org/10.1016/j.jfineco.2003.11.002

Switzer, L. N., \& Kelly, C. (2006). Corporate Governance Mechanisms and the Performance of Small- Cap Firms in Canada. International J. of Business and Ethics, 2(3). https://doi.org/10.1504/IJBGE.2006.011160

Victor, F. G., Terra, P. R. S., \& Schiehll, E. (2013). Determinants of Voluntary Executive Stock-Option Disclosure in Brazil. Journal of Management \& Governance, 17(2).

Weisbach, M. S. (1988). Outside Directors and CEO Turnover. Journal of Financial Economics, 20, 431-460. https://doi.org/10.1016/0304-405X(88)90053-0

Westphal, J., \& Zajac, E. J. (1994). Substance and symbolism in CEOs long-term incentive plans. Administrative Science Quarterly, 39, 367-391. https://doi.org/10.2307/2393295

Yermack, D. (1996). Higher Market Values of Companies with a Small Board of Directors. Journal of Financial Economics, 40, 185-211. https://doi.org/10.1016/0304-405X(95)00844-5

\section{Notes}

Note 1. Towers Perrin is a consulting firm whose mission is to help corporates improve their performance by optimally managing their human resources and their industrial and financial risks. It offers innovative solutions in the valuation of human capital and the design of human resources programs as well as in financial risk management, reinsurance intermediation and actuarial consulting. It is present in the largest industrial countries and the main financial markets.

Note 2. www.consultancy.eu/news/2118/average-top-100-ceo-in-europe-earns-salaries (11/12/2019)

Note 3. The council also appears to be a body of reflection, approval, and a source of privileged information. It does not fulfill a decision function in that it does not initiate major decisions; it is not a steering committee. However, it intervenes to ratify the decisions, in other words, to decide in last resort; it then acts as an approval body. Finally, it is also a reflection body that helps in the preparation of decisions. It represents a useful aid for the executives insofar as it appears to be a privileged source of information.

Note 4. From a disciplinary perspective advocated by the agency theory, a board of directors made up of a larger fraction of independent members, chaired by a person who does not provide the general direction, preferably of enlarged size, and who possesses a compensation committee would be better to look after the interests of the shareholders of the corporate. However, in another approach focused on access to scarce resources and the skills of directors, the board of directors should then be composed of many members and, preferably, internal members of the corporate or external members affiliated with the corporate executives. On the one hand, the skills (related to a better knowledge of the corporate) brought by the directors are superior, on the other hand, the affiliated 
members (for example, material suppliers or bankers) facilitate access to some resources.

Note 5. Non - financial benefits include paid vacation and other services provided to executives.

\section{Copyrights}

Copyright for this article is retained by the author(s), with first publication rights granted to the journal.

This is an open-access article distributed under the terms and conditions of the Creative Commons Attribution license (http://creativecommons.org/licenses/by/4.0/). 